\title{
Analysis of The Development Gross Motor and Emotional-Social Skills in Terms of Characteristics of Parents in Kindergarten Children
}

\author{
J. Ma'wa \\ Universitas Negeri Surabaya, Surabaya, Indonesia \\ jannatulmawa471@gmail.com
}

\begin{abstract}
This study aimed to analyze the development of gross motor and emotional social in terms of characteristics of parents that are democratic, authoritarian, and permissive. This research used descriptive research with a qualitative approach. The research instruments used were observation sheet and an interview guide. Data analysis techniques used are qualitative analysis with an interactive model which includes data collection, data condensation, and data presentation. The results of this study indicated that rough motor and emotional social can develop with the tendency of democratic and permissive parenting. In democratic parenting, parents pay more attention to the opinions of children, listen to child complaints, and provide freedom that remains controlled in children so that when they make mistakes can be immediately given advice to children, whereas authoritarian parenting shows no development of rough motor and social-emotional, which is caused by the pressure that is given by parents to the child to always follow the wishes of parents.
\end{abstract}

\section{Keywords—motor development; emotional-social skill}

\section{INTRODUCTION}

Children are next generations of one nation. If children are healthy so the nations will be strong and prosperous. The qualified next generations are the hopes of every parent. Therefore, we all put hopes so that children can grow physically, mentally, and socially also useful for nations and countries. Physical motor development of one child becomes special attention in some research review because physical growth processes of children can influence their life in the future (Papalia et al., 2004).

Motoric in early children is very needed, for developing children intelligence in the fields of language development, cognitive, art and creativity. Motoric is the translation from the word "motor". Gallahue (in Samsudin, 2005:32) is some biological or mechanical base that causes some movement. In another word, the movement is culmination from some action based on motoric. Motor development in kindergarten ages is based on activity. Activities of kindergarten children are $80 \%$ using physical activities.

The rough motor is body movement ability which uses big muscles, most or all body limbs. Rough motor is needed so that children can sit, kick, run, walk up and down the stairs and so on [7]. Children motor ability roles are assumed as very central for supporting their life. The motor development especially rough motor is one of very important factors [3]. Sujiono
(2007:13) stated that rough motor movement is an ability that needs coordination of most children body parts. The rough motor movement involves big muscle activities such as hand muscles, foot muscles, and all children body muscles.

Rough motor development in kindergarten aims to introduce and train gross movement, improve abilities of managing, controlling body movement and coordination, and also improves body skills and the ways of living healthy, so it can support healthy, strong, and skillful physical growth. According to the physical development aims, children are trained basic movements that will help their motor developments in the future [2]

Motor development is different in levels in every individual. The children of four years can use scissors easily whereas the others temporarily may be able to use after five or six years old. Certain children may be able to jump and catch balls where-as the others may be only able to catch big balls or roll around. More deeply Morrison (2000) revealed that motor development is children learning order that emphasizes in body movement, in which the movement plays important roles for children life especially related to attitudes and their social life.

Rough motor development problems in each kindergarten are quite different. The same case happens and is experienced by children in Kindergarten Muslimat NU 7 Pongangan Manyar Gresik. Rough motor developmental patterns of one child and others are different, the case can be seen from learning activities and rough motor indicator achievements. Partly children are still seen as less skillful to do body movement in coordination for practicing flexibility, stability, and agility. The case is seen from activities of playing the catwalk, playing climbing, running with patterns and obstacles, throwing a target, and other games, in which there are partly children who can do well by short times, whereas partly children are still less skillful in completing the games. Motor development problems are also seen from children abilities in imitating movements especially in dance and gymnastics movements, partly children are still clumsy for moving their body limbs even partly children are very late in following their teacher movements and they can't explore flexibility and agility.

Besides children rough motor problems, other problems that occur in the children in Kindergarten Muslimat NU 7 Pongangan Manyar Gresik are social-emotional developmental problems. Based on observational results, it is known that 
several problems related to socialization and children abilities for sharing and cooperating are very less. Children tend to be egoists and they do not want to relent when playing ones. Even there are several children who tend to dominate certain games. One of the learning methods that emphasize in children socialemotional developmental stimulation is playing-role-method.

Children social-emotional development can be seen in children skills in interacting with other people in social contexts by special ways that can be accepted socially and as values and in the same times, they are useful for themselves and other people [1]. Children social-emotional development should continue to be stimulated so that children have empathy feelings, in which children express their feelings, generosities, cooperations and cares.

According to Jersild (in Sobur, 2003:407) emotional development in childhood is tied very tightly by other developmental aspects. After children sense organs become stronger, children ability for knowing observation becomes stronger, children abilities for knowing differences and doing observation become more mature, and after children step more forward in all developmental aspects, phenomena totals that can raise their emotion increase more and more.

Really, parents apply different parenting patterns to their children. The case depends on social status, habits, and cultures of the places where the families live. Every parenting pattern that is applied has weaknesses and strengths respectively. The different parenting patterns can form children social characters so directly or indirectly, they can influence children social attitudes.

\section{METHOD}

This research uses descriptive method by qualitative approach referred. This research is conducted in Kindergarten Muslimat NU 7 Pongangan Manyar Gresik. The research is conducted between April and May 2017. The technique used for analyzing data in this research is descriptive technique or more specifically using interactive model.

\section{RESULT AND DISCUSSIONS}

Rough Motor Development viewed from Characteristics of Parents in Children Group B of Kindergarten Muslimat NU 7 Pongangan Manyar Gresik

Based on the observational results conducted, it shows there are differences of rough motor development in the three children who become the subjects in this research. They are the children of Group B of Kindergarten Muslimat NU 7 Pongangan Manyar Gresik. The differences can be viewed from different Parenting Patterns in guiding their children. Parenting patterns that are applied by parents have important roles in educating, guiding, disciplining and protecting children for achieving maturities according to the available norms in society.

The observational results show that good rough motor development is seen in the children who get Democratic Parenting Patterns such as in Child DA. The observational results show that Child DA can improve his/her abilities in doing movements of walking on plank board, doing movements of hanging up and clinging, doing gymnastics movements according to the rhythms, and using right and left hand in the activities of wearing clothes that get an evaluation as Developing Very Well. This case is in line with the interview results conducted to The Parents of DA that state that the child has been able to do body movement coordination such as eye, hand, foot, head as the movement of standing by one foot instability, the movement of walking on plank board and the movement of clinging well.

This case is supported by (2010) who stated that democratic parenting patterns will result independent children characteristics, and they have interests to new things. According to Santrock (2011), democratic parenting patterns are the parenting patterns that drive the children to be independent, but they still place limits and controls in their actions [6].

In applying the democratic parenting patterns, the parents of Child DA tend to give freedom to their child for wishing, always follow their child and never refuse the child demands, then they also seldom punish their child but they still control the child well, so if the child does mistakes, so they can be known and the parents give advices to their child about good things, supported by Wahyuning \& Rachmadian (2003) who stated that democratic par-enting patterns are seen in the parents who combine control and drive, in the same time the parents watch their child attitudes and drive to meet the available rules in the family by following the applied standards. The results show the successes in demo-cratic parenting patterns that can help rough motor development in children.

The successful rough motor development in children is also seen in the children who get permissive parenting patterns, i.e. in Child IK, but it is still item that is Beginning to Develop such as the child wish of asking for pardon when doing mistakes. The case is because there is the tendency of parenting patterns that give freedom to the children, always follow the children wishes, and have loose rules but less control by the parents who tend to spoil the children, so it makes the children assume trivial. The case is supported by the interview results conducted by Hurlock (2010) who stated that the parents with permissive parenting patterns tend to always follow the children wishes. These attitudes may be caused by the parents love their children excessively, protect them excessively and spoil them excessively, so whatever are done by the children will be accepted by the parents.

The case is proven from the results in this research that find that good rough motor development in Child IK happens because permissive parenting patterns applied by The Parents of Child IK. The permissive parenting patterns will result the children characteristics who are aggressive, disobedient, spoiled, less independent, always willing to win, less selfconfident and immature socially.

However, Authoritative Parenting Patterns applied by The Parents of Child EFIP show that they are less able to develop rough motor in Child EFIP who is seen that he/she has undeveloped rough motor such as the ability of standing movement by one foot in stability and the ability of using right and left hand in the activity of wearing clothes. 
The results that show that authoritative parenting patterns are less able to develop rough motor in children prove that the parenting patterns that always determine what are done by the children, the parents enforce their wishes to their children, the parents who always master their children and their children movements excessively. This case shows that authoritative parenting patterns tend to become children development obstacles especially fine motor development because the authoritative parenting patterns will cause the children are easy to have stress and afraid to do some actions so they are not motivated for doing the actions that should be done by the children of their same ages.

Social-emotional Development viewed from Parenting Patterns in Group B of Kindergarten Muslimat NU 7 Pongangan Manyar Gresik.

Based on the observational results conducted, they show differences of social-emotional development in the three children who become the subjects in this research. They are children of Group B of Kindergarten Muslimat NU 7 Pongangan Manyar Gresik. The differences can be seen clearly by the different Parenting Patterns in guiding their children. The parenting patterns applied by the parents have important roles in educating, guiding, disciplining and protecting their children for achieving maturity according to the available norms in society.

The observational results show that good Social-emotional development is seen in the children who get Democratic Parenting Patterns such as in Child DA. The observational results show that Child DA is able to control the emotions properly, has self-responsibilities, wants to ask for forgiveness when doing mistakes, and wants to play with friends, wants to care to friends, and wants to share with friends. They are Developing Very Well. The case is in line with the interview results conducted to The Parents of DA that state that the child has been able to control emotions, has strong self-confidence and never give up, they have experienced development in which the child can control the emotions properly and is not easy to give up when meeting obstacles in doing something.

The case is supported by Suparyanto (2010) who stated that democratic parenting patterns will result independent children characteristics, and they have interests to the new things. According to Santrock (2011), democratic parenting patterns are the parenting patterns that drive the children to be independent, but still place limits and controls in their actions.

The successful rough motor development in children is also seen in the children who get permissive parenting patterns, i.e. in Child IK that show that the child is able to obey rules in the games, have self-responsibility, ask for forgiveness when doing mistakes, and care to friends, but there is still result that shows as beginning to develop in the ability of controlling the emotions properly. The case happens because permissive parenting patterns tend to give freedom excessively, supported by the interview results conducted by Hurlock (2010) who stated that the parents with permissive parenting pat-terns tend to always follow their children wishes.

However, Authoritative Parenting Patterns applied by The Parents of Child EFIP show that they are less able to develop
Social Emotional in Child EFIP, it is seen there is Undeveloped Social Emotional such as less having unyielding attitudes. For the other four indicators such as having strong self-confidence, having self-responsibilities, willing to play with friends, and willing to share with friends get the evaluation as Beginning to Develop. Authoritative parenting patterns will result children characteristics who are coward, quiet, have no initiative, like to oppose, like to break norms, have weak personalities, anxious, and withdraw.

The case shows that authoritative parenting patterns tend to become children development obstacles especially socialemotional development, because the authoritative parenting patterns will cause the children are easy to have stress and afraid to do some actions so they are not motivated for doing the actions that should be done by the children of their same ages.

\section{CONCLUSION}

Rough motor and social-emotional development can improve by the tendencies of Democratic and Permissive parenting patterns. In Democratic parenting patterns, the parents give attention considerably in the children opinions, hear the children complaints, and give controlled freedom to their children so that when doing mistakes, they can give advices to their children soon. Whereas permissive parenting patterns show that there are still children who experience less good development, in which the case is caused by the freedom given without controls by their parents.

Authoritative parenting patterns show there is not developing rough motor and social-emotional, in which the case is because of the pressures given by the parents to their children for always following the parent wishes, following what are wanted by the parents without seeing the children wishes and opinions, and the parents demand for demanding the children perfections. The case makes the children feel suppressed and burdened by what are available, so it makes the children less motivated in doing the good things related to improved rough motor and social-emotional abilities.

So, the suggestions in this research are as follows: (1) It is hoped so that democratic parenting patterns can become examples in educating children by giving attention to children, giving freedom about what are wanted but still doing controls in children so that children feel motivated for doing the new things so it can help their rough motor and social emotional; (2) It is hoped so that authoritative parenting patterns can be eliminated in fostering their children because the parenting patterns give pressures and children become less free, so children want to improve their rough motor and social emotional scantily.

\section{REFERENCES}

[1] K. Coolahan, J. Fantuzzo, J. Mendez, and P. McDermott,. 'PPreschool peer interactions and readiness to learn: Relationships between classroom peer play and learning behaviors and conduct', Journal of Educational Psychology, vol.92, no.3, pp. 458-465, 2013.

[2] Depdiknas, Pedoman Pengembangan Fisik/Motorik di Taman Kanakkanak, Dikti, Jakarta, 2007.

[3] B.E. Hurlock. Perkembangan Anak. Jilid 1, Penerbit Erlangga, Jakarta, 2008 . 
[4] G.S. Morrison, Fundamentals of Early Childhood Education. 2nd Ed, Merrill Prentice Hall, Inc, USA, 2000.

[5] Samsudin, Pengembangan Motorik di Taman Kanak-kanak. Fakultas Ilmu Keolahragaan Universitas Negeri Jakarta, Jakarta, 2005.

[6] J.W. Santrock, Psikologi Pendidikan (edisi kedua), (Penerj. Tri Wibowo B.S), Kencana, Jakarta, 2011.

[7] Sunardi, \& Sunaryo, Intervensi Dini Anak Berkebutuhan Khusus, Jakarta, Departemen Pendidikan Nasional, 2007.

[8] A. Goodman, H. Joshi, B. Nasim and C. Tyler, Social and emotional skills in childhood and their long-term effects on adult life: A review for the Early Intervention Foundation, Institute of Education, 2015.

[9] Connections with the National Quality Framework, Developing children's social and emotional skills, KidsMatter Australian Early Childhood Mental Health, Australia, 2014.

[10] K.E. Adolph, and S.E. Berger, "Physical and motor development." Developmental science: An advanced textbook 5: 223-281, 2005.

[11] J. Mason, Qualitative Researching, $2^{\text {nd }}$ edition, London: SAGE Publications, ISBN 076197427 X, 2002.
[12] R.E. Riggio,, and R.J. Reichard. "The emotional and social intelligences of effective leadership: An emotional and social skill approach." Journal of managerial psychology, vol.23, no.2, pp. 169-185, 2008.

[13] Stanton-Salazar, Ricardo. "A social capital framework for understanding the socialization of racial minority children and youths." Harvard educational review, 67.1: 1-41, 1997.

[14] Early childhood development and disability: discussion paper, World Health Organization, ISBN 978924150406 5, 2012.

[15] M. Menzer, The Arts In Early Childhood: Social And Emotional Benefits Of Arts Participation, A Literature Review And Gap-Analysis (2000-2015), Washington: NEA Office of Research \& Analysis, 2015. 